\section{Healing Love or Sex Addictions with Mind-Body Coaching}

\author{
Michael Roth, C.Ad, SRC* \\ Breakthrough Addiction Recovery, California, USA
}

When we speak of addictions, most people consider drug or alcohol addictions. Others expand the term to think about addictions to food or gambling. These addictions are certainly legitimate, but there are many other forms of addiction that aren't always discussed. One such case is the addiction to sex and love.

People with addictions to sex or love often have a hard time maintaining long-term, intimate relationships. They often have multiple, simultaneous sexual or romantic partners, and may have issues with their emotional health. In this article, we're going to explain the basics of sex and love addictions so you can understand how these issues might be affecting you. We'll also talk about some steps you can take to help overcome these sexual addictions with the help of a holistic addiction recovery coach.

\section{What is a Sex or Love Addiction?}

Sex and love addictions are both process addictions. This means that the individual afflicted with the addiction is not addicted to a substance per se, but rather an action, behavior, or process. Biologically, the addiction is caused by the release of chemicals in the brain that occur when a person experiences this process.

\section{Love addiction}

Love addiction occurs when a person becomes addicted to the sensation of being loved. There are a number of things that can make a person feel loved:

Validation: One of the simplest forms of love addiction-and in fact, something that most of us struggle with to some degree-is a need for validation. It feels nice to have someone else approve of what we're doing, what we say, and who we are.

*Corresponding author: Michael Roth, C.Ad, SRC, Breakthrough Addiction Recovery, California, USA, Tel: +1 8052560372; E-mail:

Michael@BreakthroughAddictionRecovery.net

Website: https://BreakthroughAddictionRecovery.net;

Contact form: https://breakthroughaddictionrecovery.net/contact-us/

Citation: Roth M (2019) Healing Love or Sex Addictions with Mind-Body Coaching. J Addict Addictv Disord 6: 25.

Received: April 07, 2019; Accepted: April 09, 2019; Published: April 17, 2019

Copyright: $\odot 2019$ Roth M. This is an open-access article distributed under the terms of the Creative Commons Attribution License, which permits unrestricted use, distribution, and reproduction in any medium, provided the original author and source are credited.
In serious cases, people may attempt to be something other than what they are in order to feel validated. Instead of speaking their mind, they may say what they believe other people want them to say so that they feel validated. Instead of expressing their beliefs, they may adopt the beliefs of others to feel accepted.

In the case of love addictions, people strive for romantic or intimate validation. This means that they often go to great lengths to secure close, personal relationships with people-sexual or otherwise-that make them feel validated.

Grooming: It feels nice when somebody else grooms us, and it may also provide a feeling of physical validation. Some people may experience an incessant desire to be groomed by others to fulfill the needs of their addiction.

Intimacy: While intimacy can be sexual, in most cases it is not. Intimacy is a term used to describe a close, personal encounter, and it can be emotional, physical, or mental.

Many people with love addictions crave intense intimacy. They often go far out of their way to be in intimate situations with people-cuddling, kissing, holding each other or having intimate relationships. This makes them feel secure in their own being and provides them with the self-confidence to move on.

\section{Sex addiction}

Sex addictions often occur simultaneously with a love addiction. Sex is arguably the most intimate experience that a person can have, and many people are addicted to both sex and intimacy. Sex addicts often have unaddressed issues with personal intimacy or emotional health that arose during childhood.

Sex addicts have a need to frequently or constantly engage in sexual activity to feel satisfied with them. Unfortunately, the more they engage in these activities, the more dependent they become on them to be happy.

This vicious cycle leads to an increasingly intense desire for sexual activity. Sex addicts often have multiple partners and have a hard time maintaining a monogamous relationship.

Intrigue: Some people are intrigued and 'fired up' simply by the idea of sex. This can lead to issues in their interactions with the people around them, especially those they find sexually intriguing. It can also lead to excessive masturbation and the use of pornography.

Sex and masturbation: Most sex addicts engage in more sex and masturbation than the average person. They can often begin to feel depressed or agitated if they don't have sex or masturbate for an extended period.

Fantasy: One thing that many sex addicts engage in is fantasy. Fantasy can take many forms, and the exploration of these fantasies leads sexual addicts to get a deeper gratification from their sexual acts. Things like dressing up and BDSM can be considered fantasy. 


\section{Managing a sex addiction with holistic coaching}

One of the best things you can do to help manage a sex addiction is to talk to a sex addiction recovery coach. Holistic coaches can help you manage your sexual addiction in a number of ways that can be more beneficial and comprehensive than traditional therapy.

Holistic coaching takes into account the whole person, rather than looking at the addiction as the sole focus. It aims to tackle not only the issues that traditional therapy addresses, but also other aspects of the mind-body relationship. These are some of the ways a holistic coach can help you:

Somato emotional repatterning: This is a type of coaching that helps to identify abnormalities in an individual's energy flow. It's been known for some time that imbalances in an individual's energy or emotion can result in physical and psychological changes. For example, stress is known to raise the heart rate and cause sweating, and in the long-term, it can cause disease.

A sex addiction coach using Somato Emotional Repatterning will help you identify a whole scope of patterns in your mental and physical state. They will be able to draw conclusions and address the root of your sexual addiction so you can heal the problem from its core.

Neurofeedback: Neurofeedback is a process in which your coach will use specialized equipment to determine your body's responses to certain stimuli. They will help you reprogram the responses that you have to sexual stimuli and cravings so you can develop healthier patterns for living.
Supplementation and nutrition: While malnutrition won't cause sexual addiction on its own, it can certainly contribute to anxiety, depression, and other issues that may make a person feel the need to reach out sexually to feel heard and accepted. A coach may help you review your current nutritional intake or provide herbs, supplements or vitamins to help balance your sexuality.

\section{Benefits of holistic coaching}

Holistic coaching is much more comprehensive than traditional counseling because it addresses both the mind and the body, whereas traditional therapy deals mostly with the mind.

This means that the holistic coach will be able to take much more into account. They will have a better understanding of your physiology, your mental health, and your life as a whole, and they will be able to develop a clearer picture of what's actually going on in your situation.

Holistic coaching can help you eliminate the issue in a way that ensures it won't come back again. So get in touch with a holistic coach who can help you identify the root of your sex or love addiction and put you on the road to balance and recovery! 


\section{II}

Journal of Anesthesia \& Clinical Care

Journal of Addiction \& Addictive Disorders

Advances in Microbiology Research

Advances in Industrial Biotechnology

Journal of Agronomy \& Agricultural Science

Journal of AIDS Clinical Research \& STDs

Journal of Alcoholism, Drug Abuse \& Substance Dependence

Journal of Allergy Disorders \& Therapy

Journal of Alternative, Complementary \& Integrative Medicine

Journal of Alzheimer's \& Neurodegenerative Diseases

Journal of Angiology \& Vascular Surgery

Journal of Animal Research \& Veterinary Science

Archives of Zoological Studies

Archives of Urology

Journal of Atmospheric \& Earth-Sciences

Journal of Aquaculture \& Fisheries

Journal of Biotech Research \& Biochemistry

Journal of Brain \& Neuroscience Research

Journal of Cancer Biology \& Treatment

Journal of Cardiology: Study \& Research

Journal of Cell Biology \& Cell Metabolism

Journal of Clinical Dermatology \& Therapy

Journal of Clinical Immunology \& Immunotherapy

Journal of Clinical Studies \& Medical Case Reports

Journal of Community Medicine \& Public Health Care

Current Trends: Medical \& Biological Engineering

Journal of Cytology \& Tissue Biology

Journal of Dentistry: Oral Health \& Cosmesis

Journal of Diabetes \& Metabolic Disorders

Journal of Dairy Research \& Technology

Journal of Emergency Medicine Trauma \& Surgical Care

Journal of Environmental Science: Current Research

Journal of Food Science \& Nutrition

Journal of Forensic, Legal \& Investigative Sciences

Journal of Gastroenterology \& Hepatology Research

Journal of Gerontology \& Geriatric Medicine
Journal of Genetics \& Genomic Sciences

Journal of Hematology, Blood Transfusion \& Disorders

Journal of Human Endocrinology

Journal of Hospice \& Palliative Medical Care

Journal of Internal Medicine \& Primary Healthcare

Journal of Infectious \& Non Infectious Diseases

Journal of Light \& Laser: Current Trends

Journal of Modern Chemical Sciences

Journal of Medicine: Study \& Research

Journal of Nanotechnology: Nanomedicine \& Nanobiotechnology

Journal of Neonatology \& Clinical Pediatrics

Journal of Nephrology \& Renal Therapy

Journal of Non Invasive Vascular Investigation

Journal of Nuclear Medicine, Radiology \& Radiation Therapy

Journal of Obesity \& Weight Loss

Journal of Orthopedic Research \& Physiotherapy

Journal of Otolaryngology, Head \& Neck Surgery

Journal of Protein Research \& Bioinformatics

Journal of Pathology Clinical \& Medical Research

Journal of Pharmacology, Pharmaceutics \& Pharmacovigilance

Journal of Physical Medicine, Rehabilitation \& Disabilities

Journal of Plant Science: Current Research

Journal of Psychiatry, Depression \& Anxiety

Journal of Pulmonary Medicine \& Respiratory Research

Journal of Practical \& Professional Nursing

Journal of Reproductive Medicine, Gynaecology \& Obstetrics

Journal of Stem Cells Research, Development \& Therapy

Journal of Surgery: Current Trends \& Innovations

Journal of Toxicology: Current Research

Journal of Translational Science and Research

Trends in Anatomy \& Physiology

Journal of Vaccines Research \& Vaccination

Journal of Virology \& Antivirals

Archives of Surgery and Surgical Education

Sports Medicine and Injury Care Journal

International Journal of Case Reports and Therapeutic Studies

Submit Your Manuscript: http://www.heraldopenaccess.us/Online-Submission.php 